\title{
Science: it's a role model thing
}

\author{
Chris Gunter*
}

It seems like an obvious, intuitive statement, and indeed people state it everywhere as such. Girls are more likely to enter and stay in a scientific career if they have female role models who are successful in science or math; ergo, female scientists should make all efforts to serve as role models. But is it actually true?

I recently gave a talk for the Huntsville, Alabama Chapter of the American Association of University Women (AAUW), and was asked to speak about what efforts there are to get girls interested in science. What I didn't realize is that the National Research Director of AAUW, Dr Catherine Hill, would be speaking right before me and covering a lot of the same territory, based on her coauthorship of an outstanding 2010 report on women in science, technology, engineering and mathematics (STEM) [1]. There was a slightly embarrassing moment when we said different things about the effectiveness of role models, which prompted me to look into the issue more deeply.

In the great tradition of preparing talks the night before, I had looked up the 2007 report from the Institute of Education Studies entitled 'Encouraging girls in math and science' [2]. The team of authors examined existing studies and came up with five recommendations, and a label for the amount of evidence supporting each. Recommendation number 3 is 'Expose girls to female role models who have succeeded in math and science,' but the panel rates 'the level of evidence that supports this recommendation as low. So, that's what I said in my talk, and this idea did not go over well with the room.

It turns out that the panel made this rating because in 2007 the few studies they could find that documented role-model effectiveness focused on college students, and not on pre-college girls. These studies also focused more on immediate testing performance and belief in a girl's own math ability, for example, than longer-term consequences of role modeling. Since then, there has been an explosion of online efforts to involve girls and women in science, but peer-reviewed studies showing that these activities are actually effective remain scant.

*Correspondence: drchrisgunter@gmail.com

Girlscientist Consulting, Atlanta, GA 30033, USA
For test-based studies especially, a key concept is 'stereotype threat', or the effect of anxiety or negative emotion when a subject is put in a position where they might confirm a negative stereotype about themselves. Multiple analyses have demonstrated that by the time they get to college, women are affected by the stereotype that they will perform more poorly on tests. A classic example: when college students were told they were taking a test to measure their math abilities, a statement shown to invoke stereotype threat, men and women performed equivalently. When half of them were also told 'this mathematics test has not shown any gender differences in performance or mathematics ability', presumably negating the stereotype threat for women, the women performed significantly better than both the men and other women not given this second instruction [3].

Logic thus suggests if we can change the stereotype for female performance in science and math, we can avoid stereotype threat. Role modeling seems the obvious choice: show girls that women can be successful in STEM fields. Simple, right? Nope: data suggest that the type of role model presented actually matters.

Take a publication from 2008 that reported on interviews with eighth-grade girls throughout a process of getting to know female scientists [4]. Before even meeting the girls, the scientists themselves expressed the pressure they felt 'to be the perfect woman scientist to attract girls to the field.' I can completely relate to this feeling. In my experience, being a female scientist involves countless meetings being the only woman in the room. I'll never know how many people treated me differently because our interactions were through email, and my name is Chris. When I called authors I'd never met to discuss their submissions to (or rejections from) Nature, a significant fraction of the calls would start with a silence followed by 'Oh! You're a woman!'

For the last 10 years I've been contacted by plenty of other women - and have contacted others myself - asking for advice on how to succeed as a scientist and a woman. So many of the students, especially, still express to me the concern that they feel scrutinized. As a result, they feel they have to be better than the men around them, whether or not this is in fact the case. Importantly, this goes beyond the lab and extends to many other areas of their lives, in my experience. Just like the women in the 
2008 role-modeling study, the trainees I meet to this day put pressure on themselves to be nearly perfect. But the researchers concluded 'Ironically, this perfect image (which was perceived by the girls as one of superiority) could have driven the [girls] further from the profession if maintained' [4]. Instead, the girls in this study wanted to talk about everything, and not see the scientists as a stereotype but as people.

In 2012, Betz and Sekaquaptewa invited controversy with their study suggesting that 'feminine' role models can 'demotivate rather than inspire middle school girls' [5]. Their paper details two primary experiments; in the first, girls were exposed to 'role models' through magazine articles written by the experimenters, and then given a test to measure the girls' interest in future math activities. The articles differed in whether the scientists depicted were 'feminine (for example, wearing pink clothes and makeup, likes reading fashion magazines), rather than 'gender-neutral (for example, wearing dark-colored clothes and glasses, likes reading).' These feminine role models purportedly 'decreased all girls' current self-rated math interest, ability, and short-term success expectations.' In the second experiment, girls who self-identified as not interested in STEM were shown the two categories of role models, and reported they were even less interested in STEM after seeing the 'feminine' scientists [5].

Hang on - so now I should be a role model by not reading fashion magazines and not looking or acting 'perfect'? Not surprisingly, a number of female scientists responded to the 2012 study [5] with dismay, pointing out among other things that the two experiments relied on 144 and 42 girls, respectively, and the definitions of feminine and gender-neutral were based on the very stereotypes we are trying to eliminate.

Just when this debate was winding down, the European Union came out with a video intended to attract women into science titled 'Science: it's a girl thing. It's since been taken down by the EU but put back up by others, including at http://www.youtube.com/watch?v=g032MPrSjFA. Women in high heels and pink lipstick are shown dancing and laughing, intercut with other women in the lab, while a serious man at a microscope stops his work to gaze at the models. The result was a train wreck online. The real shame is that the people may not check out the accompanying website, http://science-girl-thing.eu/en, which has great information about women in science. There are video interviews with a number of students and scientists about what they do, featuring a range of dark and pink clothes. The women are presented as people who not only work in the lab, but also go to the pub with friends, and are not fashion models. On the site, girls can also see 'dream jobs' connected to a number of STEM interests.

Enthusiasm is out there: in 2012, the Girl Scout Research Institute in the US reported that $74 \%$ of high-school girls in their surveys indicated interest in STEM fields. They also reported that $91 \%$ of girls agreed with the statement 'Whatever boys can do, girls can do.' Yet in this study, 57\% of the girls said that if they went into a STEM career, they'd 'have to work harder than a man just to be taken seriously'. And approximately 30\% still agreed with the statement 'Employers in the fields of STEM don't usually want to hire women' [6]. Eek! The interest in science careers is clearly present, but the stereotype is as well.

Let's say you're a scientist, and you know a child who may be interested in a STEM career. Given all of these contradictions, what are you to do? My plan would be twofold: to reduce stereotype threat and to be myself as a role model. Of course in order for the stereotype that girls perform worse in STEM to be removed, both girls and boys have to learn that it's not true. Currently bucking the cliché: the winners of the first two Google Science Fairs in 2011 and 2012, with first place going to girls both years and all three winners being girls in 2011 .

Some resources you can use:

- the European Science Foundation asked for girls to submit videos in response to the train wreck, and the winners are at http://www.gender-summit.eu/index. php/video-contest.

- websites such as http://www.greatscienceforgirls.org/, which offer complete evidence-based curricula for afterschool programs that can help interest girls (and boys) in science. The NSF-funded program called Girls RISE in Miami, http://www.miamisci.org/girlsrise/ explorations.html, also offers some experiments and reports on their experience with an afterschool program.

- competitions such as http://stemchallenge.org/ in the US, for designing video games, and http://www. stemchallenges.net/ in the UK, a series of math and science competitions leading up to the 2012 Olympics.

- blog sites such as http://doublexsciencejr.blogspot. com/, where kids can submit blog posts of their experiments or their own explanations of scientific phenomena. (Disclosure: I am an editor for the sister site, Double X Science [http://www.doublexscience.org/].)

- any local afterschool or summer programs which relate to STEM. In the Girl Scout report, at most 36\% of the girls indicated they had taken this opportunity [6].

As for being a role model, I think all that any of us can do is be ourselves and make an effort to interact with kids and show them what you look like as a scientist. This goes for both men and women: a classic and fun example is described at http://ed.fnal.gov/projects/scientists/index. html, comparing student drawings before and after meeting scientists at Fermilab. This is one of the reasons I am active on Twitter, and why I volunteer to speak at my child's school on science night, among other things. 
Maybe my nails are painted that night, and maybe they're not. What the data do support is that any relationship I can form with students, boy or girl, will help to combat the stereotype and show them that women can be scientists.

\section{Abbreviation}

STEM, science, technology, engineering and mathematics.

Published: 14 February 2013

\section{References}

1. Hill C, Corbett C, St Rose A: Why so few? Women in science, technology, engineering, and mathematics. Washington, DC: American Association of University Women; 2010 [http://www.aauw.org/learn/research/whysofew.cfm]

2. Halpern D, Aronson J, Reimer N, Simpkins S, Star JR, Wentzel K: Encouraging girls in math and science: IES practice guide (NCER 2007-2003).

Washington, DC: National Center for Education Research, Institute of

Education Sciences, US Department of Education; 2007

[http://ies.ed.gov/ncee/wwc/PracticeGuide.aspx?sid=5]
3. Good C, Aronson J, Harder JA: Problems in the pipeline: Stereotype threat and women's achievement in high-level math courses. J Appl Develop Psychol 2008, 29:17-28.

4. Buck GA, Clark VLP, Leslie-Pelecky D, Lu Y, Cerda-Lizarraga P: Examining the cognitive processes used by adolescent girls and women scientists in identifying science role models: A feminist approach. Sci Educ 2008, 92:688-707.

5. Betz DE, Sekaquaptewa D: My fair physicist? Feminine math and science role models demotivate young girls. Social Psychol Personality Sci 2012, 3:738-746

6. Modi K, Schoenberg J, Salmond K: Generation STEM: What girls say about science, engineering, technology, and math. New York, NY: Girl Scouts of the USA; 2012 [http://www.girlscouts.org/research/publications/stem/ generation_stem_what_girls_say.asp]

doi:10.1186/gb-2013-14-2-105

Cite this article as: Gunter C: Science: it's a role model thing. Genome Biology 2013, 14:105. 